\title{
Synthesis and in vitro Evaluation of Antifungal Properties of Some 4-Aryl-3-Methyl-1,2,3,4-Tetrahydroquinolines Derivatives
}

\author{
Arnold R. Romero Bohórquez ${ }^{1} \bowtie$, Vladimir V. Kouznetsov $^{1}$, Susana A. Zacchino ${ }^{2}$
}

\begin{abstract}
Two series of 4-aryl-3-methyl-1,2,3,4-tetrahydroquinoline derivatives were efficiently synthesized according to a twostep synthesis and evaluated as potential antifungal agents. The key step was the formation of the corresponding $N$-benzyltetrahydroquinolines 5 via a three-component cationic imino Diels-Alder cycloaddition. The second step was a catalytic debenzylation to obtain the $N$-unprotected tetrahydroquinolines 6 . The products were isolated and purified by column chromatography. Substances were characterized using nuclear magnetic resonance (NMR) mass spectrometry (MS) and infrared spectroscopy (IR). All compounds were tested in vitro against standardized, clinically important fungi, including yeasts, hialohyphomycetes, and dermatophytes. These studies showed that between the tetrahydroquinoline series tested, compounds $6 \mathrm{f}$ and $6 \mathrm{~g}$ showed antifungal activity, specifically against dermatophytes. The compound 6-methoxy-4-(4-hydroxi-3-methoxyphenyl)-3-methyl-1,2,3,4-tetrahydroquinoline $6 \mathrm{~g}$ exhibited the best in vitro activity (MIC 32-65 $\mu \mathrm{g} / \mathrm{mL}$ ). The results indicated that the elimination of benzyl group from the $\mathrm{N}$-benzyltetrahydroquinolines derivatives, as well as the introduction of a hydroxyl group in the 4-aryl substituent caused a significant improvement in the antifungal activity. These results were supplemented by the in silico prediction; most of the tetrahydroquinolines evaluated showed high bioavailability, high drugs score and low potential risk.
\end{abstract}

Keywords: antifungal activity; tetrahydroquinolines; cationic imino Diels-Alder reaction; Lipinski’s rule; propenylbenzenes

Edited by Alberto Acosta $\bowtie$

1. Laboratorio de Química Orgánica y Biomolecular, Parque

Tecnológico Guatiguará, Universidad Industrial de Santander,

A.A. 678, Piedecuesta, Colombia.

2. Farmacognosia, Facultad de Ciencias Bioquímicas y Farmacéuticas, Universidad Nacional de Rosario. Suipacha 531, 2000-Rosario, Argentina.

Received: 01-07-2014 Accepted: 11-09-2014

Published on line: 29-09-2014

Citation: Romero Bohórquez AR, Kouznetsov VV, Zacchino SA (2015) Synthesis and in vitro Evaluation of Antifungal Properties of Some 4-Aryl-3-Methyl-1,2,3,4-Tetrahydroquinolines Derivatives. Universitas Scientiarum 20(2): 177-189 doi: 10.11144/Javeriana.SC20-2.siea

Funding: Universidad Industrial de Santander; COLCIENCIAS.

Electronic supplementary material: N/A

\section{Introduction}

Fungal infections are a common and serious public health issue that can threaten human life, particularly in immunocompromised patients; they have a remarkable impact on morbidity and mortality worldwide especially in tropical and subtropical developing countries (Mathew \& Nath 2009, Pappas 2011, Brown et al. 2012). The majority of fungal infections are caused by opportunistic pathogens, which may be endogenous or acquired from the environment. Candida, Cryptococcus and Aspergillus infections are the most common invasive mycotic diseases that affect humans (Pfaller et al. 2006, Senet et al. 2012). However, new fungal pathogens that pose a risk at a global scale have emerged, and their incidence continues to 
increase (Seebacher et al. 2008, Galimberti et al. 2012). Some forms of dermatomycoses produced by fungal microorganisms cause high morbidity; they affect the quality of life of patients with AIDS, patients receiving anticancer chemotherapy, or those undergoing organ transplants (Hsu et al. 2011, Ramos-e-Silva et al. 2012). The prevalence of superficial mycotic infections is high; $20 \%$ of the world's population has skin mycoses, making superficial mycotic infections one of the most frequent forms of infection (Woodfolk 2005, Havlickova et al. 2008). Dermatophytic fungi of the genera Trichophyton, Epidermophyton, and Microsporum produce superficial mycoses. This fungi group specifically infects the keratin tissues of the body, causing superficial infections of the skin, hair, or nails, because of their ability to obtain nutrients from keratinized material (Grappel et al. 1974, Weitzman \& Summerbell 1995). Significant advances have been made in the development and evaluation of new antifungal agents, especially for superficial mycoses (Kathiravan et al. 2012, Rotta et al. 2012). Although imidazole compounds such as clotrimazole and miconazole have proven to be an effective treatment for dermatomycoses (Boucher et al. 2004, Chai et al. 2011), these fungal infections are often very difficult to eradicate (Li et al. 1995, Zacchino et al. 1999). The clinical efficacy of current antifungal drugs has been limited because of drug resistance, high toxicity risks, and insufficiencies in their antifungal activity and undesirable side effects (Marr et al. 1997, Sanglard 2002). There is a need to develop new, safe and efficient chemotherapeutic agents with potent antifungal activity. As a result, developing new broadspectrum antifungal agents with less toxicity and a better pharmacokinetic profile is crucial.

Because of their remarkable pharmacological applications, natural and synthetic quinoline compounds and their partially reduced derivatives, tetrahydroquinoline, are heterocycles of great importance in medicinal chemistry (Kouznetsov 2009, Sridharan et al. 2011). These compounds have displayed different biological activities, such as antiplasmodial activity (Jaquemond-Collet et al. 2002); they are estrogen receptor modulators (Chen et al. 2007, Wallace et al. 2013) and are, therefore, considered attractive scaffolds for the development of new antifungal agents. Examples of these molecules include a heterocyclic compound with significant antibiotic properties, called helquinoline 1 (Asolkar et al. 2004), the antifungal agent ( $N$-tetrahydroquinoline) urea derivative 2, which has displayed an MIC value of $12.5 \mu \mathrm{g} / \mathrm{mL}$ against $A$. Niger and T. Rubrum, respectively (Zheng et al. 2010), the 2-(4-pyridinyl)1,2,3,4-tetrahydroquinoline derivative 3 , which is highly active against Aspergillus spp. (MIC $=31.2 \mu \mathrm{g}$ / $\mathrm{mL}$ ) and especially against dermatophytes (MIC $=8$ $\mu \mathrm{g} / \mathrm{mL}$ ). More recently, Gutierrez et al. (2012) reported the 2-(furan-2-yl)-1,2,3,4-tetrahydroquinoline 4, which displayed interesting phytopathogenic fungi bioactivity against Cladosporium cladosporoides with MIC values of $13.75 \mu \mathrm{g} / \mathrm{mL}$.

In the course of our screening for novel and selective bioactive compounds, we have reported the antiparasitic and antifungal activity of some substituted N-heterocycles, including some (tetrahydro)quinolines (Vargas et al. 2003, 2010, Romero et al. 2012, Kouznetsov et al. 2012, Fonseca et al. 2013). Considering our previous reports and continuing with our program in search of new antifungal agents, we decided to prepare different polyfuntionalized 1,2,3,4-tetrahydroquinolines and test their biological properties. Here, we report the synthesis and in vitro antifungal activity of several 4-aryl-3-methyl tetrahydroquinoline derivatives (5a-h) and (6a-h) against standardized, as well as clinically important fungi including Cryptococcus neoformans, several species of Candida and Aspergillus genus, and dermatophytes. These THQ compounds were prepared using a three-component cationic imino Diels-Alder cycloaddition methodology and a catalytic reduction (Romero \& Kouznetsov 2010) that provided the N-benzyl- or N-H-1,2,3,4-tetrahydroquinoline derivatives with high structural diversity.

\section{Materials \& methods}

\section{In silico pharmacological properties study}

The preliminary molecular design for 4-aryl-3-methyl1,2,3,4-tetrahydroquinoline compounds series 5 and 6 was achieved based on structure-activity relationship studies and virtual screening analyses reported in the literature. Five physicochemical parameters of Lipinski's rules were calculated using the Molinspiration virtual platform (http://www.molinspira tion.com/ 
services/). The profile and toxicity risk assessment was accomplished using the OSIRIS program (http:// www.organic-chemistry.org/prog/peo). The OSIRIS and Molinspiration Property Explorers, shown in these web-pages, are an integral part of some pharmaceutical companies' in-bouse substance registration system. They allow drawing chemical structures and calculates on-the-fly various drug-relevant properties whenever a structure is valid.

\section{Chemistry}

The melting points (uncorrected) were determined using a Fisher-Johns melting point apparatus. We recorded IR spectra on a Lumex Infralum FT-02 spectrophotometer in $\mathrm{KBr} .{ }^{1} \mathrm{H}$ and ${ }^{13} \mathrm{C}$ NMR spectra were measured on a Bruker AM-400 spectrometer (400 $\mathrm{MHz}{ }^{1} \mathrm{H}$ NMR and $100 \mathrm{MHz}{ }^{13} \mathrm{C} \mathrm{NMR}$ ), using $\mathrm{CDCl}_{3}$ as solvent. TMS was used as an internal standard. J values are reported in $\mathrm{Hz}$; chemical shifts are reported in $\mathrm{ppm}(\delta)$ relative to the solvent peak $\left(\mathrm{CHCl}_{3}\right.$ in $\mathrm{CDCl}_{3}$ at $7.26 \mathrm{ppm}$ for protons). Signals were designated as follows: s, singlet; $d$, doublet; dd, doublet of doublets; ddd, doublet of doublets of doublets; $t$, triplet; td, triplet of doublets; q, quartet; m, multiplet; br., broad. A Hewlett Packard 5890a Series II Gas Chromatograph interfaced to an HP 5972 Mass Selective Detector with an HP MS ChemStation Data system was used for MS identification at 70 $\mathrm{eV}$ using a $60 \mathrm{~m}$ capillary column coated with HP-5 [5\% phenylpoly(dimethylsiloxane)]. We performed elemental analyses on a Perkin-Elmer 2400 Series II analyzer, which were within \pm 0.4 of theoretical values. The reaction progress was monitored using thin layer chromatography on Silufol UV 254 TLC aluminum sheets. Column chromatography was carried out using Silica gel (60-120 mesh). All reagents were purchased from Sigma and Aldrich Chemical Co. and used without further purification.

\section{General Procedure for the synthesis of N-Benzyl-4- aryl-3-methyltetrabydroquinoline derivatives}

The general procedure was previously described by Romero \& Kouznetsov (2010) and performed as follows: A mixture of $\mathrm{N}$-benzylaniline $(1 \mathrm{mmol})$ and formaldehyde $(37 \%$ in $\mathrm{MeOH}, 1.1 \mathrm{mmol})$ in $\mathrm{MeCN}$ $(10 \mathrm{~mL})$ was stirred at r.t. for $10 \mathrm{~min}$. The system was cooled to $0{ }^{\circ} \mathrm{C}$ and $\mathrm{BF}_{3}$. $\mathrm{OEt}_{2}(1.1 \mathrm{mmol})$ was added dropwise into the mixture. After $30 \mathrm{~min}$, dienophile reagent (trans-anethole or trans-isoeugenol; $1.1 \mathrm{mmol}$ ) was added to the reaction mixture over $5 \mathrm{~min}$. We stirred the resulting mixture at $70{ }^{\circ} \mathrm{C}$ for $8 \mathrm{~h}$. After completion of the reaction as indicated by TLC, the reaction mixture was extracted with EtOAc $(3 \times$ $15 \mathrm{~mL})$. The organic layer was separated and dried $\left(\mathrm{Na}_{2} \mathrm{SO}_{4}\right)$, then, concentrated in vacuo and the crude product was purified by column chromatography using silica gel (60-120 mesh; petroleum ether-EtOAc) to afford pure tetrahydroquinoline $5 \mathrm{a}-\mathrm{h}$.

\section{Selected Spectral Data}

trans - N-B e n z y 1-3, 6 - d i m e th y 1 - 4 - ( 4 methoxyphenyl)-1,2,3,4-tetrahydroquinoline (5b): This compound was isolated as a white solid with a melting point (Mp) of $88-90{ }^{\circ} \mathrm{C}$. The molecular characterization was carried out with infrared (IR) spectroscopy; it showed the following characteristic signals: 3024, 2962, 1620, 1512, $1250 \mathrm{~cm}^{-1}$. Mass spectrometry (MS) gave a molecular ion peak of $m / z=357\left(65, \mathrm{M}^{+*}\right)$. Nuclear magnetic resonance on protons ${ }^{1} \mathrm{H} \mathrm{NMR}\left(400 \mathrm{MHz}, \mathrm{CDCl}_{3} \mathrm{Me}_{4} \mathrm{Si}\right)$ showed $\delta$ (ppm) to be: $0.92\left(3 \mathrm{H}, \mathrm{d}, J=6.7 \mathrm{~Hz}, 3-\mathrm{CH}_{3}\right), 2.08(3 \mathrm{H}$, s, 6- $\left.\mathrm{CH}_{3}\right), 2.19(1 \mathrm{H}, \mathrm{m}, \mathrm{H}-3), 3.03(1 \mathrm{H}, \mathrm{dd}, J=11.4$, $\left.7.9 \mathrm{~Hz}, \mathrm{H}-2_{\mathrm{ax}}\right), 3.27$ (1H, dd, $\left.J=11.4,3.7 \mathrm{~Hz}, \mathrm{H}-2_{\mathrm{eq}}\right)$, $3.62(1 \mathrm{H}, \mathrm{d}, J=7.8 \mathrm{~Hz}, \mathrm{H}-4), 3.80\left(3 \mathrm{H}, \mathrm{s}, 4^{\prime}-\mathrm{OCH}_{3}\right)$, $4.49\left(2 \mathrm{H}, \mathrm{s}, \mathrm{N}-\mathrm{CH}_{2}-\mathrm{Ph}\right), 6.49$ (2H, m, H-8 and $\left.\mathrm{H}-5\right)$, $6.80(1 \mathrm{H}, \mathrm{dd}, J=8.5,1.5 \mathrm{~Hz}, \mathrm{H}-7), 6.84(2 \mathrm{H}, \mathrm{d}, J=8.6$ $\left.\mathrm{Hz}, 2^{\prime}-\mathrm{ArH}\right), 7.01$ (2H, d, J = 8.6 Hz, 3'-ArH), 7.22$7.34(5 \mathrm{H}, \mathrm{m}, \mathrm{PhH}) ;{ }^{13} \mathrm{C}-\mathrm{NMR}\left(100 \mathrm{~Hz}, \mathrm{CDCl}_{3} \mathrm{Me}_{4} \mathrm{Si}\right)$, $\delta$ (ppm): 157.9, 143.2, 139.2, 137.9, 131.0, 129.9 (2C), 128.5 (2C), 127.8, 126.7 (2C), 126.6, 125.0, 124.5, 113.6 (2C), 111.0, 55.6, 55.2, 54.5, 50.7, 34.8, 20.3, 18.2. Anal. Calcd for $\mathrm{C}_{25} \mathrm{H}_{27} \mathrm{NO}(357 \mathrm{~g} / \mathrm{mol})$ : C, 83.99; H, 7.61; N, 3.92. Found: C, 83.78; H, 7.72; N, 3.88.

trans- $N$-Benzyl-3,6-dimethyl-4-(4-hydroxy-3methoxyphenyl)-1,2,3,4-tetrahydroquinoline (5f): This compound was isolated as a white solid with a melting point (Mp) of $127-129{ }^{\circ} \mathrm{C}$. The molecular characterization was carried out with infrared (IR) spectroscopy showed the following characteristic signals: 3433, 3024, 2916, 1612, 1512, $1273 \mathrm{~cm}^{-1}$. Mass spectrometry (MS) gave a molecular ion peak of $\mathrm{m} / \mathrm{z}=$ $373\left(77, \mathrm{M}^{+*}\right)$. Nuclear magnetic resonance on protons ${ }^{1} \mathrm{H}$ NMR (400 MHz, $\mathrm{CDCl}_{3} \mathrm{Me}_{4} \mathrm{Si}$ ) showed $\delta$ (ppm) to be: $0.99\left(3 \mathrm{H}, \mathrm{d}, J=6.7 \mathrm{~Hz}, 3-\mathrm{CH}_{3}\right), 2.15\left(3 \mathrm{H}, \mathrm{s}, 6-\mathrm{CH}_{3}\right)$, 
$2.27(1 \mathrm{H}, \mathrm{m}, \mathrm{H}-3), 3.12\left(1 \mathrm{H}, \mathrm{dd}, J=11.3,8.2 \mathrm{~Hz}, \mathrm{H}-2_{\mathrm{ax}}\right)$, $3.36\left(1 \mathrm{H}, \mathrm{dd}, J=11.4,3.8 \mathrm{~Hz}, \mathrm{H}-2_{\mathrm{eq}}\right), 3.67(1 \mathrm{H}, \mathrm{d}, J=$ $8.1 \mathrm{~Hz}, \mathrm{H}-4), 3.87$ (3H, s, 3'-OCH 3 ), 4.55 (2H, br. d, $J=$ $\left.7.2 \mathrm{~Hz}, \mathrm{~N}-\mathrm{CH}_{2}-\mathrm{Ph}\right), 5.58$ (1H, s, 4'-OH), 6.57 (1H, br. $\mathrm{d}, J=8.4 \mathrm{~Hz}, \mathrm{H}-8), 6.59$ (1H, br. s, H-5), 6.69 (2H, br. $\mathrm{d}, J=8.3, \mathrm{~Hz}, 2^{\prime}-\mathrm{ArH}$ y 6 '-ArH $), 6.86(1 \mathrm{H}, \mathrm{dd}, J=8.2$, $1.4 \mathrm{~Hz}, \mathrm{H}-7), 6.88$ (1H, d, $J=8.0 \mathrm{~Hz}, 5$ '-ArH), 7.26$7.40(5 \mathrm{H}, \mathrm{m}, \mathrm{PhH}) .{ }^{13} \mathrm{C}-\mathrm{NMR}\left(100 \mathrm{~Hz}, \mathrm{CDCl}_{3} \mathrm{Me}_{4} \mathrm{Si}\right)$, $\delta$ (ppm): 146.5, 143.9, 143.2, 139.2, 137.6, 130.9, 128.5 (2C), 127.8, 126.7, 126.7 (2C), 125.1, 124.5, 122.2, 114.0, 111.1, 110.9, 55.9, 55.6, 54.7, 51.3, 34.7, 20.2, 18.3. Anal. Calcd for $\mathrm{C}_{25} \mathrm{H}_{27} \mathrm{NO}_{2}(373 \mathrm{~g} / \mathrm{mol}): \mathrm{C}, 80.40 ; \mathrm{H}, 7.29 ; \mathrm{N}$, 3.75. Found: C, 80.58; H, 7.10; N, 3.65.

\section{General procedure synthesis of $\mathrm{N}-\mathrm{H}-4-\mathrm{Aryl}-3-$ methyltetrabydroquinoline derivatives}

The general procedure also was previously described by Romero \& Kouznetsov (2010) and performed as follows: A mixture of tetrahydroquinoline $5 \mathrm{a}-\mathrm{h}$ ( $1 \mathrm{mmol}$ ), wet $10 \% \mathrm{Pd} / \mathrm{C}$ (cat.) and $\mathrm{MeOH}-\mathrm{CH}_{2} \mathrm{Cl}_{2}$ (3:1, $20 \mathrm{~mL})$ was stirred under $\mathrm{H}_{2}(1 \mathrm{~atm})$ at r.t. for 14-16 h. The reaction mixture was filtered, and the filtrate was concentrated in vacuo and extracted with $\mathrm{CH}_{2} \mathrm{Cl}_{2}(3 \times 15 \mathrm{~mL})$. The organic layer was separated and dried $\left(\mathrm{Na}_{2} \mathrm{SO}_{4}\right)$, and concentrated again in vacuo. We purified the resulting product by flash column chromatography (silica gel; petroleum ether-EtOAc) to provide the pure tetrahydroquinoline $6 \mathrm{a}-\mathrm{h}$.

\section{Selected Spectral Data}

trans-3,6-Dimethyl-4-(4-methoxyphenyl)-1,2,3,4tetrahydroquinoline (6b): This compound was isolated as a yellow solid with a melting point (Mp) of $71-73^{\circ} \mathrm{C}$. The molecular characterization was carried out using infrared (IR) spectroscopy; it showed the following characteristic signals: 3412, 2962, 1604, $1504 \mathrm{~cm}^{-1}$. Mass spectrometry (MS) gave a molecular ion peak of $\mathrm{m} / \mathrm{z}=267\left(65, \mathrm{M}^{+*}\right)$. Nuclear magnetic resonance on protons ${ }^{1} \mathrm{H}$ NMR $\left(400 \mathrm{MHz}, \mathrm{CDCl}_{3}\right.$ $\mathrm{Me}_{4} \mathrm{Si}$ ) showed $\delta(\mathrm{ppm})$ to be: $0.91(3 \mathrm{H}, \mathrm{d}, J=6.7 \mathrm{~Hz}$, 3- $\left.\mathrm{CH}_{3}\right), 2.08$ (4H, br. s, 6- $\mathrm{CH}_{3}$ and $\left.\mathrm{H}-3\right), 2.98(1 \mathrm{H}, \mathrm{dd}$, $\left.J=11.1,8.5 \mathrm{~Hz}, \mathrm{H}-2_{\mathrm{ax}}\right), 3.24(1 \mathrm{H}, \mathrm{dd}, J=11.2,3.5$ $\left.\mathrm{Hz}, \mathrm{H}-2_{\text {eq }}\right), 3.56(1 \mathrm{H}, \mathrm{d}, J=8.2 \mathrm{~Hz}, \mathrm{H}-4), 3.80(3 \mathrm{H}, \mathrm{s}$, 4'- $\left.\mathrm{OCH}_{3}\right), 6.46(2 \mathrm{H}$, br. d, $J=8.1 \mathrm{~Hz}, \mathrm{H}-8$ y H-5), 6.79 $(1 \mathrm{H}, \mathrm{dd}, J=8.1,1.4 \mathrm{~Hz}, \mathrm{H}-7), 6.83(2 \mathrm{H}, \mathrm{d}, J=8.6 \mathrm{~Hz}$, 2'-ArH), 7.03 (2H, d, $J=8.6 \mathrm{~Hz}, 3$ '-ArH). ${ }^{13} \mathrm{C}-\mathrm{NMR}$ $\left(100 \mathrm{~Hz}, \mathrm{CDCl}_{3} \mathrm{Me}_{4} \mathrm{Si}\right), \delta$ (ppm): 157.9, 142.3, 138.0, 131.0, 130.0 (2C), 127.6, 126.3, 124.3, 114.1, 113.6
(2C), 55.2, 50.4, 47.2, 35.3, 20.4, 18.0. Anal. Calcd for $\mathrm{C}_{18} \mathrm{H}_{21} \mathrm{NO}(267 \mathrm{~g} / \mathrm{mol}): \mathrm{C}, 80.86 ; \mathrm{H}, 7.92 ; \mathrm{N}, 5.24$. Found: C, 81.02; H, 7.78; N, 5.10.

trans - 3, 6- D i m e t h y 1 - 4 - ( 4 - h y d r o x y - 3 methoxyphenyl)-1,2,3,4-tetrahidroquinoline (6f): This compound was isolated as a white solid with a melting point (Mp) of $139-141{ }^{\circ} \mathrm{C}$. The molecular characterization carried out with infrared spectroscopy (IR) showed the following characteristic signals: 3548, 3425, 2924, 1612, $1512 \mathrm{~cm}^{-1}$. Mass spectrometry (MS) gave a molecular ion peak of $m / z=283\left(59, \mathrm{M}^{+*}\right)$; Nuclear magnetic resonance on protons ${ }^{1} \mathrm{H}$ NMR (400 $\mathrm{MHz}, \mathrm{CDCl}_{3} \mathrm{Me}_{4} \mathrm{Si}$ ) showed $\delta(\mathrm{ppm})$ to be: $0.93(3 \mathrm{H}$, d, $\left.J=6.6 \mathrm{~Hz}, 3-\mathrm{CH}_{3}\right), 2.12$ (4H, br. s, $\mathrm{H}-3$ and $6-\mathrm{CH}_{3}$ ), $3.02\left(1 \mathrm{H}, \mathrm{dd}, J=10.7,9.2 \mathrm{~Hz}, \mathrm{H}-2_{\mathrm{ax}}\right), 3.29(1 \mathrm{H}, \mathrm{dd}, J=$ 11.1, 3.1 Hz, H-2 $\left.{ }_{\text {eq }}\right), 3.56(1 \mathrm{H}, \mathrm{d}, J=8.5 \mathrm{~Hz}, \mathrm{H}-4), 3.82$ $\left(3 \mathrm{H}, \mathrm{s}, 3\right.$ '- $\left.\mathrm{OCH}_{3}\right), 4.64(1 \mathrm{H}$, br. s, 4'-OH), 6.49 (2H, br. d, $J=8.0 \mathrm{~Hz}, \mathrm{H}-5$ y H-8), 6.63 (1H, br. s, 2'-ArH), 6.66 $\left(1 \mathrm{H}, \mathrm{dd}, J=8.8 \mathrm{~Hz}, 6^{\prime}-\mathrm{ArH}\right), 6.82(1 \mathrm{H}, \mathrm{dd}, J=7.7 \mathrm{~Hz}$, H-7), 6.86 (1H, d, J = 7.9 Hz, 5'-ArH). ${ }^{13} \mathrm{C}-\mathrm{NMR}$ (100 $\left.\mathrm{Hz}, \mathrm{CDCl}_{3} \mathrm{Me}_{4} \mathrm{Si}\right), \delta$ (ppm), presents the following data: 146.5, 144.0, 142.2, 137.6, 130.9, 127.5, 126.4, 124.4, 122.3, 114.2, 113.9, 111.1, 55.9, 51.1, 47.5, 35.3, 20.4, 18.0. Anal. Calcd for $\mathrm{C}_{18} \mathrm{H}_{21} \mathrm{NO}_{2}(283 \mathrm{~g} / \mathrm{mol})$ : C, 76.29; H, 7.47; N, 4.94. Found: C, 75.98; H, 7.68; N, 4.81.

\section{Biology}

\section{Microorganisms and media}

For the first screening in the antifungal evaluation, we used standardized strains of Candida albicans ATCC 10231, Candida tropicalis CCC 131, Saccharomyces cerevisiae ATCC 9763, Cryptococcus neoformans ATCC 32264, A. fumigatus ATTC 26934, A. niger ATCC 9029, Trichophyton rubrum CCC 110, T. mentagrophytes ATCC 9972 and M. gypseum CCC 115 from the American Type Culture Collection (ATCC), Rockville, MD, USA, and CEREMIC (CCC), and the Centro de Referencia en Micología, Facultad de Ciencias Bioquímicas y Farmacéuticas, Suipacha 531-(2000)-Rosario, Argentina. The strains were grown on Sabouraud-chloramphenicol agar slants for $48 \mathrm{~h}$ at $30^{\circ} \mathrm{C}$, and maintained on slopes of Sabouraud-Dextrose agar (SDA, Oxoid); they were sub-cultured every 15 days to prevent pleomorphic transformations. Inocula of cell or spore suspensions were obtained according to reported procedures and adjusted to $1-5 \times 10^{-3}$ cells/spores with colony forming units (CFU)/mL (CLSI 2008 a,b). 


\section{Antifungal susceptibility testing}

The minimum inhibitory concentration (MIC) of each compound was determined by using broth microdilution techniques according to the guidelines of the National Committee for Clinical Laboratory Standards for yeasts (M27-A3)(CLSI 2008 a) and filamentous fungi (M 38-A2)(CLSI 2008 b). MIC values were determined in RPMI-1640 (Sigma, St. Louis, Mo, USA) buffered to $\mathrm{pH} 7.0$ with MOPS. Microtiter trays were incubated at $30^{\circ} \mathrm{C}$ for yeasts and species of Aspergillus and $28-30^{\circ} \mathrm{C}$ for dermatophytes in a moist, dark chamber. MICs were visually recorded at $48 \mathrm{~h}$ for yeasts, and at intervals according to control fungus growth for the rest of fungi.

For the assay, stock solutions of pure compounds were twofold diluted with RPMI from 250-0.98 $\mu \mathrm{g} / \mathrm{mL}$ (final volume $=100 \mu \mathrm{l}$ ) and a final DMSO concentration $\leq 1 \%$. A volume of $100 \mu \mathrm{l}$ of an inoculum suspension was added to each well with the exception of the sterility control (sterile water was added instead). We used ketoconazole (Sigma Chem. Co.) and terbinafine (Novartis, Bs. As.) as positive controls. Endpoints recorded in Table 4 were defined as the lowest concentration of drug resulting in total inhibition $\left(\mathrm{MIC}_{100}\right)$ of visual growth compared to the growth in the control wells containing no antifungal. We conducted all tests in duplicate and considered compounds with MICs $>250 \mu \mathrm{g} / \mathrm{mL}$ as inactive.

\section{Results}

\section{In silico chemoinformatics tools}

The pre-screening for hit identification from synthetic compounds libraries was based on the oral bioavailability using Lipinski's rules concepts (Lipinski et al. 1997) through the analysis of the rule of five, employing Molinspiration free software (Table 1).

We calculated the principal molecular properties, including the number of hydrogen donors $(\mathrm{nNHOH})$, number of hydrogen acceptors ( $\mathrm{nNO}$ ), number of rotatable bonds (nRB) and molecular weight

Table 1. Calculated Lipinski's rule of five parameters for the 4-aryl-3-methyl-1,2,3,4- tetrahydroquinolines (5, 6) assayed. ${ }^{a}$ Confirmed by elemental analysis with $\pm 0.5 \%$ of calculated values. ${ }^{b}$ Number of hydrogen bond acceptors. ${ }^{c}$ Number of hydrogen bond donors. ${ }^{d}$ Number of rotatable bonds. Reference drug: Ketoconazole (Ket) and terbinafine (Terb).

\begin{tabular}{|c|c|c|c|c|c|c|c|c|}
\hline \multirow[t]{2}{*}{ Comp. } & \multirow[t]{2}{*}{ Mol. formula } & \multirow{2}{*}{ MW,g/mol } & \multicolumn{6}{|c|}{ Parameters } \\
\hline & & & $\log P$ & TPSA, $\AA$ & $\mathbf{n N O}^{b}$ & $\mathrm{nOHNH}^{c}$ & $\mathbf{R B N}^{d}$ & Violations \\
\hline $5 \mathrm{a}$ & $\mathrm{C}_{24} \mathrm{H}_{25} \mathrm{NO}$ & 347.47 & 5.619 & 12.472 & 2 & 0 & 4 & 1 \\
\hline $5 b$ & $\mathrm{C}_{25} \mathrm{H}_{27} \mathrm{NO}$ & 357.50 & 6.044 & 12.472 & 2 & 0 & 4 & 1 \\
\hline $5 c$ & $\mathrm{C}_{25} \mathrm{H}_{27} \mathrm{NO}_{2}$ & 373.50 & 5.652 & 21.706 & 3 & 0 & 5 & 1 \\
\hline $5 \mathrm{~d}$ & $\mathrm{C}_{24} \mathrm{H}_{24} \mathrm{CINO}$ & 377.92 & 6.273 & 12.472 & 2 & 0 & 4 & 1 \\
\hline $5 e$ & $\mathrm{C}_{24} \mathrm{H}_{25} \mathrm{NO}_{2}$ & 359.47 & 4.902 & 32.700 & 3 & 1 & 4 & 0 \\
\hline $5 f$ & $\mathrm{C}_{25} \mathrm{H}_{27} \mathrm{NO}_{2}$ & 373.50 & 5.326 & 32.700 & 3 & 1 & 4 & 1 \\
\hline $5 g$ & $\mathrm{C}_{24} \mathrm{H}_{27} \mathrm{NO}_{3}$ & 389.50 & 4.934 & 41.934 & 4 & 1 & 5 & 0 \\
\hline $5 \mathrm{~h}$ & $\mathrm{C}_{24} \mathrm{H}_{24} \mathrm{ClNO}_{2}$ & 393.91 & 5.556 & 32.700 & 3 & 1 & 4 & 1 \\
\hline $6 a$ & $\mathrm{C}_{17} \mathrm{H}_{19} \mathrm{NO}$ & 253.34 & 3.976 & 21.261 & 2 & 1 & 2 & 0 \\
\hline $6 \mathrm{~b}$ & $\mathrm{C}_{18} \mathrm{H}_{21} \mathrm{NO}$ & 267.37 & 4.400 & 21.261 & 2 & 1 & 2 & 0 \\
\hline $6 c$ & $\mathrm{C}_{18} \mathrm{H}_{21} \mathrm{NO}_{2}$ & 283.37 & 4.009 & 30.495 & 3 & 1 & 3 & 0 \\
\hline $6 d$ & $\mathrm{C}_{17} \mathrm{H}_{18} \mathrm{ClNO}$ & 287.79 & 4.630 & 21.261 & 2 & 1 & 2 & 0 \\
\hline $6 e$ & $\mathrm{C}_{17} \mathrm{H}_{19} \mathrm{NO}_{2}$ & 269.34 & 3.258 & 41.489 & 3 & 2 & 2 & 0 \\
\hline $6 f$ & $\mathrm{C}_{18} \mathrm{H}_{21} \mathrm{NO}_{2}$ & 283.37 & 3.683 & 41.489 & 3 & 2 & 2 & 0 \\
\hline $6 g$ & $\mathrm{C}_{18} \mathrm{H}_{21} \mathrm{NO}_{3}$ & 299.34 & 3.291 & 50.723 & 4 & 2 & 3 & 0 \\
\hline $6 \mathrm{~h}$ & $\mathrm{C}_{17} \mathrm{H}_{18} \mathrm{ClNO}_{2}$ & 303.79 & 3.912 & 41.489 & 3 & 2 & 2 & 0 \\
\hline Ket & $\mathrm{C}_{26} \mathrm{H}_{28} \mathrm{Cl}_{2} \mathrm{~N}_{4} \mathrm{O}_{4}$ & 531.44 & 3.772 & 69.075 & 8 & 0 & 7 & 1 \\
\hline Terb & $\mathrm{C}_{21} \mathrm{H}_{25} \mathrm{~N}$ & 291.43 & 5.719 & 3.238 & 1 & 0 & 4 & 1 \\
\hline
\end{tabular}


(MW), as well as, another recognized parameter for membrane permeation, prerequisite for bioavailability, the topological polar surface area (TPSA) (Table 1). Other molecular properties tested for the potential risk assessment and associated to some fragments of the synthesized tetrahydroquinoline compounds were evaluated employing Osiris software (Table 2).

Table 2. Toxicity risk, drug-likeness and drug-score parameters obtained for the 4-aryl-3-methyl-1,2,3,4tetrahydroquinolines $(5,6)$ assayed. " Colors code for potential risk: drug-conform, middle risk, undesired effects. ${ }^{b}$ (Mut.) possible mutagenic, (Tum.) tumorigenic, (Irr.) irritant and (Rep. Eff.) reproductive effective.

\section{Potential Risk ${ }^{a, b}$}

\begin{tabular}{|c|c|c|c|c|c|c|}
\hline 宅 & $\stackrel{\dot{E}}{\Sigma}$ & $\underset{\xi}{\Xi}$ & $\doteq$ & 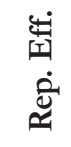 & bo & 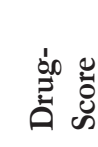 \\
\hline $5 \mathrm{a}$ & & & & & 4.78 & 0.57 \\
\hline $5 b$ & & & & & 3.31 & 0.50 \\
\hline $5 c$ & & & & & 4.54 & 0.57 \\
\hline $5 \mathrm{~d}$ & & & & & 4.79 & 0.45 \\
\hline $5 e$ & & & & & 4.87 & 0.62 \\
\hline $5 f$ & & & & & 3.35 & 0.55 \\
\hline $5 \mathrm{~g}$ & & & & & 4.58 & 0.61 \\
\hline $5 \mathrm{~h}$ & & & & & 4.83 & 0.48 \\
\hline $6 a$ & & & & & 2.87 & 0.79 \\
\hline $6 \mathrm{~b}$ & & & & & 1.33 & 0.68 \\
\hline $6 c$ & & & & & 2.60 & 0.62 \\
\hline $6 \mathrm{~d}$ & & & & & 2.88 & 0.68 \\
\hline $6 e$ & & & & & 2.98 & 0.82 \\
\hline $6 \mathrm{f}$ & & & & & 1.38 & 0.72 \\
\hline $6 \mathrm{~g}$ & & & & & 2.65 & 0.65 \\
\hline $6 \mathrm{~h}$ & & & & & 2.93 & 0.72 \\
\hline Terb & & & & & -3.84 & 0.17 \\
\hline Ket & & & & & 0.17 & 0.63 \\
\hline
\end{tabular}

The data from this topological analysis allowed us to obtain information on fragments with possible mutagenic (Mut.), tumorigenic (Tum.), irritant (Irr.) and effective reproductive (Eff. Rep.) effects. Prediction results were valued, and color-coded. Properties with medium risks of undesired effects like a mutagenicity or poor intestinal absorption are shown in light orange while green indicates that the substance evaluated has a drug-like behavior. Final molecular properties calculated in this work were the drug-score and the drug-likeness (Table 2). The molecular fragments with frequent occurrence in trade drugs yield positive druglikeness values.

\section{Chemistry}

Two series of 4-aryl-3-methyl-1,2,3,4tetrahydroquinolines derivatives were easily and efficiently synthesized according to a two-step synthesis. The first and key step was the formation of the corresponding $N$-benzyltetrahydroquinolines 5 via a "one pot" three-component cationic imino Diels-Alder cycloaddition from readily available $N$-benzylanilines, inexpensive formalin $37 \%$ formaldehyde in methanol), and a commercially available trans-anethole (and isoeugenol) in the presence of $\mathrm{BF}_{3}$. $\mathrm{OEt}_{2}$ at 70 ${ }^{\circ} \mathrm{C}$ in acetonitrile, according to the literature procedure (Romero \& Kouznetsov 2010). The second step was their catalytic debenzylation using hydrogen gas and $\mathrm{Pd} / \mathrm{C}$ as catalyst to obtain the respective $\mathrm{N}$-unprotected tetrahydroquinolines 6 (Figure 1).

Both series of compounds were obtained in good yields after column chromatography purification on silica gel (Table 3). The stereochemistry of all these tetrahydroquinoline compounds synthesized $(5,6)$ were determined by IR and MS and confirmed by ${ }^{1} \mathrm{H}$ and ${ }^{13} \mathrm{C}$ NMR spectroscopy and supported by inversedetected 2D NMR experiments (COSY, HSQC and HMBC spectra).

\section{Antifungal assays}

The in vitro antifungal activity of the 4-aryl-3-methyl1,2,3,4-tetrahydroquinolines series $5 \mathrm{a}-\mathrm{h}$ and $6 \mathrm{a}-\mathrm{h}$ was evaluated against standardized clinically important fungi, including yeasts, hialohyphomycetes, and dermatophytes (Table 4). To carry out the antifungal evaluation, concentrations of compounds up to 
<smiles>CO[C@H]1C[C@H](C)Nc2c(C(=O)O)cccc21</smiles>

1<smiles>O=C(N1CCOCC1)N1CCCc2ccccc21</smiles>

2<smiles>CC1CC(c2ccncc2)Nc2ccccc21</smiles>

3

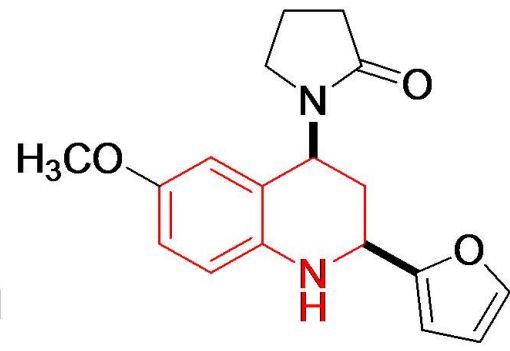

4

Fig. 1. Tetrahydroquinolines derivatives with remarkable antifungal activity.

Table 3. Physico-chemical data of the 4-aryl-3-methyl1,2,3,4-tetrahydroquinolines (5,6). ${ }^{a}$ Isolated yield after column chromatography; ${ }^{b}$ Melting point Uncorrected.

\begin{tabular}{|c|c|c|c|c|c|}
\hline Comp. & $\mathbf{R}_{1}$ & $\mathbf{R}_{2}$ & $\mathbf{R}_{3}$ & m.p., ${ }^{\circ} \mathbf{C}^{a}$ & Yield, $\%^{b}$ \\
\hline $5 a$ & $\mathrm{H}$ & $\mathrm{CH}_{3}$ & $\mathrm{H}$ & 89-91 & 59 \\
\hline $5 b$ & $\mathrm{CH}_{3}$ & $\mathrm{CH}_{3}$ & $\mathrm{H}$ & 88-90 & 61 \\
\hline $5 c$ & $\mathrm{OCH}_{3}$ & $\mathrm{CH}_{3}$ & $\mathrm{H}$ & 113-115 & 67 \\
\hline $5 d$ & $\mathrm{Cl}$ & $\mathrm{CH}_{3}$ & $\mathrm{H}$ & $125-127$ & 76 \\
\hline $5 e$ & $\mathrm{H}$ & $\mathrm{H}$ & $\mathrm{OCH}_{3}$ & 167-169 & 49 \\
\hline $5 f$ & $\mathrm{CH}_{3}$ & $\mathrm{H}$ & $\mathrm{OCH}_{3}$ & $127-129$ & 76 \\
\hline $5 g$ & $\mathrm{OCH}_{3}$ & $\mathrm{H}$ & $\mathrm{OCH}_{3}$ & 121-123 & 60 \\
\hline $5 \mathrm{~h}$ & $\mathrm{Cl}$ & $\mathrm{H}$ & $\mathrm{OCH}_{3}$ & 136-138 & 77 \\
\hline $6 a$ & $\mathrm{H}$ & $\mathrm{CH}_{3}$ & $\mathrm{H}$ & $73-75$ & 94 \\
\hline $6 \mathrm{~b}$ & $\mathrm{CH}_{3}$ & $\mathrm{CH}_{3}$ & $\mathrm{H}$ & $71-73$ & 92 \\
\hline $6 c$ & $\mathrm{OCH}_{3}$ & $\mathrm{CH}_{3}$ & $\mathrm{H}$ & Sticky oil & 95 \\
\hline $6 d$ & $\mathrm{Cl}$ & $\mathrm{CH}_{3}$ & $\mathrm{H}$ & 116-118 & 93 \\
\hline $6 e$ & $\mathrm{H}$ & $\mathrm{H}$ & $\mathrm{OCH}_{3}$ & $118-120$ & 96 \\
\hline of & $\mathrm{CH}_{3}$ & $\mathrm{H}$ & $\mathrm{OCH}_{3}$ & 139-141 & 96 \\
\hline $6 \mathrm{~g}$ & $\mathrm{OCH}_{3}$ & $\mathrm{H}$ & $\mathrm{OCH}_{3}$ & $118-120$ & 98 \\
\hline $6 \mathrm{~h}$ & $\mathrm{Cl}$ & $\mathrm{H}$ & $\mathrm{OCH}_{3}$ & $112-114$ & 97 \\
\hline
\end{tabular}

$250 \mu \mathrm{g} / \mathrm{mL}$ were incorporated to growth media according to CLSI standardized procedures (CLSI 2008 a,b). Terbinafine (Terb) and ketoconazole (Ket) were used as positive controls under the same assay conditions. Table 4 summarizes the minimum concentration of compounds thatcompletelyinhibited the growth (MIC100) obtained by nine opportunistic pathogenic fungi including yeasts (Candida albicans, C.neoformans, Saccharomycescerevisiae), hialohyphomycetes (Aspergillus spp.) as well as dermatophytes (Microsporum and Trichophyton spp.). Table 4 shows the structure of each tetrahydroquinoline derivative to facilitate the analysis of the results.

\section{Discussion}

The recognizable need to combat diseases caused by pathogenic fungi has brought about significant advancement in the development and implementation of strategies to obtain new and more potent antifungal agents. In this regard, the pursuit of effective and safer drug against pathogens fungi is an urgent priority. With the preceding in mind and considering that the tetrahydroquinoline ring is a key structural scaffold in many bioactive heterocyclic compounds, including some antifungal agents; here, we report the synthesis, characterization and results of the antifungal assays of the two series of 3-methyl-4-aryl1,2,3,4-tetrahydroquinolines $5 \mathrm{a}-\mathrm{h}$ and $6 \mathrm{a}-\mathrm{h}$. 


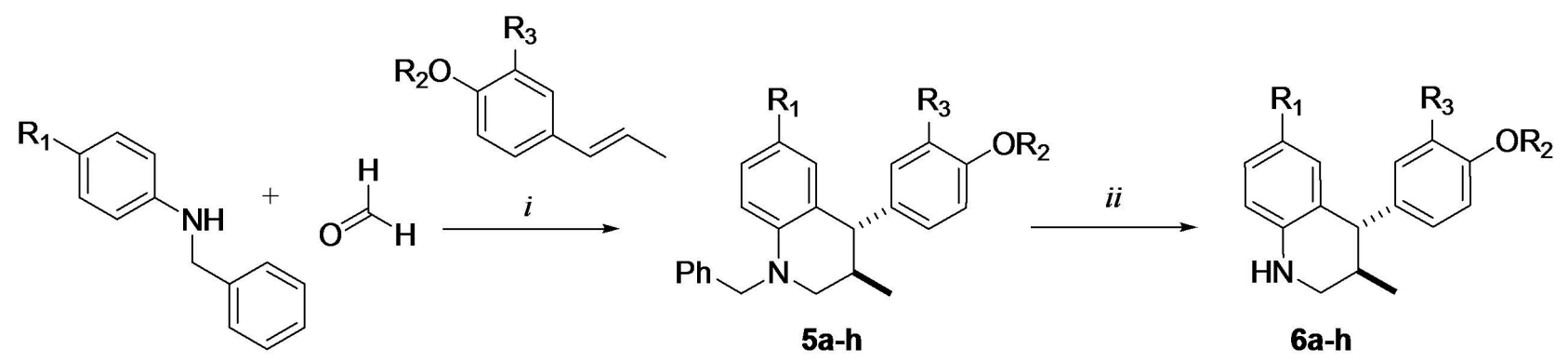

Fig. 2. Preparation of substituted 3-methyl-4-aryl-1,2,3,4-tetrahydroquinolines (5,6): Reagents and conditions: ( 2 ) $\mathrm{BF}_{3} . \mathrm{OEt}_{2}(1$ mmol), dry acetonitrile, reflux $\left(70{ }^{\circ} \mathrm{C}\right), 6-8$ h.; (ii) wet $10 \% \mathrm{Pd} / \mathrm{C}$ (cat.), $\mathrm{MeOH} / \mathrm{CH}_{2} \mathrm{Cl}_{2}(3: 1), \mathrm{H}_{2}(1 \mathrm{~atm}$.), r.t., $14-16$ h.

\section{Chemistry}

Figure 2 illustrates the overall synthesis route of the N-benzyl-3-methyl-4-aryl-1,2,3,4tetrahydroquinoline derivatives 5 and its debenzylated analogous THQs 6; this includes the cycloaddition reaction used as a key-step based on the $\mathrm{BF}_{3}$. $\mathrm{OEt}_{2-}$ catalyzed multicomponent cationic imino DielsAlder reaction among substituted $N$-benzylanilines, formalin (37\% formaldehyde in methanol), and propenylbenzenes (trans-anethole and isoeugenol) at $70{ }^{\circ} \mathrm{C}$ in $\mathrm{CH}_{3} \mathrm{CN}$ for $6-8$ hours. The catalytic debenzylation $(10 \mathrm{~mol} \% \quad \mathrm{Pd} / \mathrm{C})$ using hydrogen gas $\left(\mathrm{H}_{2}\right)$ at room temperature over night yielded the corresponding 3-methyl-4-aryl-1,2,3,4tetrahydroquinoline derivatives 6 . Both series of tetrahydroquinolines were largely obtained as stable solid substances with defined melting points and 49-77\% (5a-h) and 93-98\% (6a-h) yields after their chromatography purification (Table 3). All the studied tetrahydroquinolines were isolated and purified by column chromatography (on silica gel) using petroleum ether/ethyl acetate mixtures with gradients of polarity. We confirmed the stereochemistry of all THQ compounds using 1D and 2D NMR experiments. ${ }^{1} \mathrm{H}$ NMR analysis indicated that the structure of the distinctive diastereoisomers obtained for 5 and 6 were trans-configured with respect to the 3- $\mathrm{CH}_{3} / 4$-Ar substituents (Figure 2).

\section{In silico chemoinformatics tools}

The most significant theoretical pharmacokinetic parameters for all tetrahydroquinoline derivatives synthesized (5a-h and $6 \mathrm{a}-\mathrm{h})$ in this work were obtained using chemoinformatics platforms. Molinspiration software was used to obtain five properties associated with the Lipinski' rules (Lipinski et al. 1997) that indicate whether a chemical can be orally active in humans (drug-likeness). TPSA parameters (Chohan et al. 2010) proved to be a very good descriptor to characterize drug absorption, including intestinal absorption and bioavailability and blood-brain barrier penetration. We found that tetrahydroquinoline derivatives $5 \mathrm{a}-\mathrm{h}$ violate no more than one of Lipinski' rules while the debenzylated derivatives 6a-h meets the five criteria. All the analyzed tetrahydroquinoline compounds showed high bioavailability properties, similar and comparable with the structures of reference drugs (ketoconazole and terbinafine), largely fulfilling all the parameters set by this rule (molecular weight $=253.34-393.91, \log \mathrm{P}=3.26-6.27, \mathrm{nON}=$ $2-4$ and $\mathrm{nOHNH}=0-2)$. Prediction results by TPSA parameters for the compounds $5 \mathrm{a}-\mathrm{h}$ and $6 \mathrm{a}-\mathrm{h}$ (Table 1) showed TPSA values between 12.5 and $50.7 \AA^{2}$, confirming that this pharmacokinetic parameter is a relevant property in drug design. It should be noted that TPSA values less than $60 \AA^{2}$ are defined for compounds with good membrane permeability, as well as penetration of the blood-brain barrier.

In order to assess the possible pharmacological properties and predict the compounds drug-score of the tetrahydroquinolines $5 \mathrm{a}-\mathrm{h}$ and $6 \mathrm{a}-\mathrm{h}$, a toxicity profile evaluation was performed employing the OSIRIS software. Exploring virtually the potential risk associated to different fragments of the synthesized tetrahydroquinoline compounds, it can be noted that 
Table 4. Minimum inhibitory concentrations (MIC in $\mathrm{g} / \mathrm{mL}$ ) of N-benzyl-4-aryl-3-methyl -1,2,3,4-tetrahydroquinoline (5) and N-H-4aryl-3-methyl -1,2,3,4-tetrahydroquinoline derivatives (6). Ca: Candida albicans ATCC 10231, Ct: Candida tropicalis CCC 131, Sc: Saccharomyces cerevisiae ATCC 9763, Cn: Cryptococcus neoformans ATCC 32264, Afu: Aspergillus fumigatus ATCC 26934, An: Aspergillus niger ATCC 9029, Mg: Microsporum gypseum CCC 115, Tr: Trichophyton rubrum CCC 113, Tm: Trichophyton mentagrophytes ATCC 9972. CCC = CEREMIC (Centro de Referencia en Micologia). ATCC: American Type Culture Collection. MIC $\geq 250 \mathrm{~g} / \mathrm{mL}$ is indicative that the compound is inactive, Reference drug: ketoconazole (Ket) and terbinafine (Terb).

\begin{tabular}{|c|c|c|c|c|c|c|c|c|c|c|}
\hline Compd. & Structure & $C a$ & $C t$ & $S c$ & $C n$ & $A f u$ & $A n i$ & $M g$ & $T r$ & $\operatorname{Tm}$ \\
\hline $5 a$ & & $>250$ & $>250$ & $>250$ & $>250$ & $>250$ & $>250$ & $>250$ & $>250$ & $>250$ \\
\hline $5 b$ & & $>250$ & $>250$ & $>250$ & $>250$ & $>250$ & $>250$ & 250 & 250 & 250 \\
\hline $5 c$ & & $>250$ & $>250$ & $>250$ & $>250$ & $>250$ & $>250$ & 250 & 250 & 250 \\
\hline $5 d$ & & $>250$ & $>250$ & $>250$ & $>250$ & $>250$ & $>250$ & $>250$ & $>250$ & $>250$ \\
\hline $5 e$ & & $>250$ & $>250$ & $>250$ & $>250$ & $>250$ & $>250$ & $>250$ & $>250$ & $>250$ \\
\hline $5 f$ & & $>250$ & $>250$ & $>250$ & $>250$ & $>250$ & $>250$ & 250 & 250 & 250 \\
\hline $5 g$ & & $>250$ & $>250$ & $>250$ & $>250$ & $>250$ & $>250$ & 250 & 250 & 250 \\
\hline $5 \mathrm{~h}$ & & $>250$ & $>250$ & $>250$ & $>250$ & $>250$ & $>250$ & $>250$ & $>250$ & $>250$ \\
\hline $6 a$ & & $>250$ & $>250$ & $>250$ & $>250$ & $>250$ & $>250$ & $>250$ & $>250$ & $>250$ \\
\hline $6 \mathrm{~b}$ & & $>250$ & $>250$ & $>250$ & $>250$ & $>250$ & $>250$ & $>250$ & $>250$ & $>250$ \\
\hline $6 c$ & & $>250$ & $>250$ & $>250$ & $>250$ & $>250$ & $>250$ & 125 & 125 & 125 \\
\hline $6 \mathrm{~d}$ & & $>250$ & $>250$ & $>250$ & $>250$ & $>250$ & $>250$ & $>250$ & $>250$ & $>250$ \\
\hline $6 e$ & & $>250$ & $>250$ & $>250$ & $>250$ & $>250$ & $>250$ & $>250$ & $>250$ & $>250$ \\
\hline $6 f$ & & $>250$ & $>250$ & $>250$ & $>250$ & $>250$ & $>250$ & 31,25 & 62,5 & 62,5 \\
\hline
\end{tabular}


all obtained and evaluated products presented low biological risks and have few negative effect. The methoxy group in the $6 \mathrm{c}$ and $6 \mathrm{~g}$ compounds on the C-6 position of the tetrahydroquinoline scaffolds showed a moderate mutagenic risk. Nevertheless, the fragments and topology of the reference compound present higher potential risk than all the tetrahydroquinoline molecules evaluated. Performing calculations on drug-likeness and drug-score parameters, we could note that both series afforded favorable numbers, especially for the molecular structures 6a-h. Compared with the antifungal activity of the most active molecules ( $6 \mathrm{f}$ and $6 \mathrm{~g}$ ), the druglikeness calculation showed good correlation and confirmed the importance of removing the benzyl group, and the introduction of a hydroxyl group in the 4-aryl substituent of the tetrahydroquinoline structure (Table 3). Furthermore, the drug-score obtained for each analyzed molecule showed an important relationship with the in vitro antifungal evaluation for tetrahydroquinolines of and $6 \mathrm{~g}$, whose values were above the average of all calculated compounds.

\section{Antifungal assays}

All compounds were tested in vitro against standardized clinically important fungi, including yeasts, hialohyphomycetes, and dermatophytes. Table 3 presents the results for antifungal activities of all the title compounds; ketoconazole and terbinafine were used as the controls. The table also shows the structure of each tetrahydroquinoline derivative to facilitate the analysis of the results. Between the two tetrahydroquinoline series tested, the results showed that $\mathrm{N}$-H-tetrahydroquinoline derivatives 6a-h have moderate inhibition activities while the N-benzyltetrahydroquinoline series $5 \mathrm{a}-\mathrm{h}$ showed no antifungal activity (their MIC exceeded $250 \mu \mathrm{g} / \mathrm{mL}$ ).

Compounds 6c, of and $6 \mathrm{~g}$ showed particular antifungal activity against the dermatophyte strains assayed. The 6-methoxy-4-(4-hydroxy-3methoxyphenyl)-3-methyl-1,2,3,4-tetrahydroquinoline $6 \mathrm{~g}$ exhibit the best in vitro antifungal activity, especially against dermatophytes, including Microsporum gypseum (MIC $31.25 \mu \mathrm{g} / \mathrm{mL}$ ), Trichophyton rubrum (MIC $62.5 \mu \mathrm{g}$ / $\mathrm{mL}$ ) and Trichophyton mentagrophytes (MIC $62.5 \mu \mathrm{g} / \mathrm{mL}$ ).

Seeking structural parameters that might enhance antifungal activity, we introduced chlorine, methoxy, and methyl substituents onto the 2,4-diaryl 1,2,3,4-tetrahydroquinoline ring; we also used two different dienophiles for the cycloaddition reaction (anethole and isoeugenol) and performed $\mathrm{N}$-debenzylation of the tetrahydroquinoline derivatives 5a-h. Antifungal results indicated that the presence of the methoxy group in compounds 6 showed noteworthy performance; this compound presented bioactivity in comparison to all the other tetrahydroquinoline derivatives tested. Furthermore, inhibition activity results indicated that the elimination of a benzyl group and introduction of a hydroxyl group on 4-aryl substituent of the $\mathrm{N}$-benzyltetrahydroquinolines derivatives $5 \mathrm{a}-\mathrm{h}$ generated a significant improvement of the antifungal activity of this series (Table 3).

\section{Conclusion}

An easy and efficient synthetic route was employed to prepare two series of 4-aryl-3-methyl-1,2,3,4tetrahydroquinoline derivatives. The key step involved a three-component cationic imino DielsAlder reaction. This study showed that between the tetrahydroquinolines (THQ) series tested, compounds $6 \mathrm{f}$ and $6 \mathrm{~g}$ showed antifungal activity, specifically against dermatophytes (MIC $\leq 62.5 \mu \mathrm{g}$ / $\mathrm{mL}$ ). The compound 6-methoxy-4-(4-hydroxy-3methoxyphenyl)-3-methyl-1,2,3,4-tetrahydroquinoline $6 \mathrm{~g}$ exhibited the best in vitro activity (MIC 32-65 $\mu \mathrm{g} / \mathrm{mL}$ ). Results indicated that the elimination of a benzyl group from the $N$-benzyltetrahydroquinolines derivatives and the introduction of a hydroxyl group in the 4-aryl substituent produced a significant improvement in antifungal activity. These results were complemented by an in silico prediction, which revealed the high bioavailability, high drugs score and low potential risk of most of thevtetrahydroquinolines evaluated. We are currently pursuing more complete structure-activity relationship studies to increase in vitro antifungal activity.

\section{Acknowledgments}

The authors appreciate the financial support provided by the Universidad Industrial de Santander (VIE-UIS, project 5714). ARRB thanks COLCIENCIAS for the PhD studies scholarship (2005-2010). 


\section{Conflict of Interest}

The authors declare that no conflicts of interest exist in relation to this work.

\section{References}

Asolkar RN, Schroeder D, Heckmann R, Lang S, WagnerDoebler I, Laatsch H (2004) Marine bacteria XXVII. Helquinoline, a new tetrahydroquinoline antibiotic from Janibacter limosus Hel 1. The Journal of Antibiotics 57:17-23 doi: $10.7164 /$ antibiotics. 57.17

Brown GD, Denning DW, Levitz SM (2012) Tackling human fungal infections. Science 336:647 doi: 10.1126/ science.1222236

Boucher HW, Groll AH, Chiou CC, Walsh TJ (2004) Newer systemic antifungal agents. Drugs 64:1997-2020 doi: 10.2165/00003495-200464180-00001

Chai X, Zhang J, Cao Y,Zou Y, Wu Q, Zhang D, et al. (2011) New azoles with antifungal activity: Design, synthesis, and molecular docking. Bioorganic \& Medicinal Chemistry Letters 21:686-689 doi: 10.1016/j.bmcl.2010.12.006

Chen W, Lin Z, Ning M, Yang C, Yan X, Xie Y, et al. (2007) Aza analogues of equol: novel ligands for estrogen receptor beta. Bioorganic \& Medicinal Chemistry 15:58285836 doi: 10.1016/j.bmc.2007.05.071

Chohan ZH, Youssoufi MH, Jarranpour A, Hadda TB (2010) Identification of antibacterial and antifungal pharmacophore sites for potent bacteria and fungi inhibition: indolenyl sulfonamide derivatives. European Journal of Medicinal Chemistry 45:1189-1199 doi: 10.1016/j.ejmech.2009.11.029

CLSI, Clinical and Laboratory Standards Institute (formerly NCCLS, National Committee for Clinical and Laboratory Standards). Method M27-A3, 3rd ed.; Wayne, Ed.; NCCLS: Pennsylvania, 2008; Vol. 28 (14), pp 1-25.

CLSI, Clinical and Laboratory Standards Institute (formerly NCCLS, National Committee for Clinical and Laboratory Standards). Method M-38-A2, 2nd ed.; Wayne, Ed.; NCCLS: Pennsylvania, 2008; Vol. 28 (16), pp 1-35.

Fonseca-Berzal C, Merchán DR, Romero Bohórquez AR, Escario JA, Kouznetsov VV, Gómez-Barrio A (2013) Selective activity of 2,4-diaryl-1,2,3,4tetrahydroquinolines on Trypanosoma cruzi epimastigotes and amastigotes expressing $\beta$-galactosidase. Bioorganic \& Medicinal Chemistry Letters 23:4851-4856 doi: 10.1016/j. bmcl.2013.06.079

Galimberti R, Torre AC, Baztán MC, Rodriguez-Chiappetta F (2012) Emerging systemic fungal infections. Clinics in Dermatology 30:633-650 doi: 10.1016/j. clindermatol.2012.01.011
Grappel SF, Bishop CT, Blank, F (1974) Immunology of Dermatophytes and Dermatophytosis. Bacteriological Reviews 38:222-250

Gutiérrez M, Carmona U, Vallejos G, Astudillo L (2012) Antifungal activity of tetrahydroquinolines against some phytopathogenic fungi. Zeitschrift für Naturforschung C: A Journal of Biosciences 67:551-556

Havlickova B, Czaika VA, Friedrich M (2008) Epidemiological trends in skin mycoses worldwide. Mycoses 51:2-15 doi: 10.1111/j.1439-0507.2008.01606.x

Hsu JL, Ruoss SJ, Bower ND, Lin M, Holodniy M, Stevens DA (2011) Diagnosing invasive fungal disease in critically ill patients. Critical Reviews in Microbiology 37:277312 doi: 10.3109/1040841X.2011.581223

Jaquemond-Collet I, Benoit-Vical T, Mustofa V, Stanislas E, Mallié M (2002) Antiplasmodial and cytotoxic activity of galipinine and other tetrahydroquinolines from Galipea Officinalis. Planta Medica 2002, 68, 68-69 doi: 10.1055/s-2002-19869

Kathiravan MK, Salake AB, Chothe AS, Dudhe PB, Watode RP, Mukta MS, et al. (2012) The biology and chemistry of antifungal agents: A review. Bioorganic \& Medicinal Chemistry 20:5678-5698 doi: 10.1016/j. bmc.2012.04.045

Kouznetsov VV (2009) Recent Synthetic Developments in a Powerful Imino Diels-Alder Reaction (Povarov Reaction): Application to the Synthesis of $\mathrm{N}$-polyheterocycles and Related Alkaloids. Tetrahedron 65:2721-2750 doi: 10.1016/j.tet.2008.12.059

Kouznetsov VV, Meléndez Gómez CM, Derita MD, Svetaz L, del Olmo E, Zacchino SA (2012) Synthesis and antifungal activity of diverse C-2 pyridinyl and pyridinylvinyl substituted quinolines. Bioorganic \& Medicinal Chemistry 20:6506-6512 doi: 10.1016/j. bmc.2012.08.036

Li E, Clark AM, Hufford CD (1995) Antifungal evaluation of pseudolaric acid B, a major constituent of Pseudolarix kaempferi. Journal of Natural Products 58:5767 doi: 10.1021/np50115a007

Lipinski CA, Lombardo F, Dominy BW, Feeney PJ (1997) Experimental and computational approaches to estimate solubility and permeability in drug discovery and development settings. Advanced Drug Delivery Revienss 23:3-26 doi: 10.1016/S0169-409X(00)00129-0

Marr KA, White TC, van Burik JA, Bowden RA (1997) Development of fluconazole resistance in Candida albicans causing disseminated infection in a patient undergoing marrow transplantation. Clinical Infectious Diseases 25:908-910 doi: 10.1086/515553

Mathew BP, Nath, M (2009) Recent Approaches to Antifungal Therapy for Invasive Mycoses. ChemMedChem 4:310-323 doi: $10.1002 /$ cmdc.200800353 
Pappas, PG (2011) The role of azoles in the treatment of invasive mycoses: review of the Infectious Diseases Society of America guidelines. Current Opinion in Infectious Diseases 24:S1-S13 doi: 10.1097/01. qco.0000399602.83515.ac

Pfaller MA, Pappas PG, Wingard JR (2006) Invasive Fungal Pathogens: Current Epidemiological Trends. Clinical Infections Diseases 43:S3-S14 doi: 10.1086/504490

Ramos-e-Silva M, Oliveira CM, Schechtman RC, Trope BM, Carneiro, S (2012) Systemic mycoses in immunodepressed patients (AIDS). Clinics in Dermatology 30:616-627 doi: 10.1016/j.clindermatol.2012.01.008

Romero Bohórquez AR, Escobar P, Leal SM, Kouznetsov VV (2012) In Vitro Activity Against Trypanosoma cruzi and Leishmania chagasi Parasites of 2,4-Diaryl 1,2,3,4-Tetrahydroquinoline Derivatives. Letters in Drug Design \& Discovery 9:802-808 doi: 10.2174/157018012802652994

Romero Bohórquez AR, Kouznetsov VV (2010) An Efficient and Short Synthesis of 4-Aryl-3methyltetrahydroquinolines from $N$-Benzylanilines and Propenylbenzenes through Cationic Imino DielsAlder Reactions. Synlett 6:970-972 doi: 10.1055/s-00291219571

Rotta I, Otuki MF, Conegero AC, Correr CJ (2012) Efficacy of topical antifungal drugs in different dermatomycoses: a systematic review with metaanalysis. Revista da Associação Médica Brasileira 58:308-318 doi: 10.1590/S0104-42302012000300010

Sanglard D (2002) Resistance of human fungal pathogens to antifungal drugs. Current Opinion in Microbiology 5:379385 doi: 10.1016/S1369-5274(02)00344-2

Senet P, Tichotova L, Votruba I, Buchta V, Spulak M, Kunes J, et al. (2010) Antifungal 3,5-disubstituted furanones: from 5-acyloxymethyl to 5-alkylidene derivatives. Bioorganic Medicinal Chemistry 18:1988-2000 doi: 10.1016/j.bmc.2010.01.030

Seebacher C, Bouchara JP, Mignon B (2008) Updates on the epidemiology of dermatophyte infections. Mycopathologia 166:335-352 doi: 10.1007/s11046-008-9100-9

Sridharan V, Suryavanshi PA, MenéndezJC (2011) Advances in the chemistry of tetrahydroquinolines. Chemical Reviews 111:7157-7259 doi: 10.1021/cr100307m

Vargas-Méndez LY, Zacchino SA, Kouznetsov VV (2010) Synthesis of New 4-Methyl-2-(4-pyridyl)-1,2,3,4tetrahydroquinolines as Potent Antifungal Compounds. Journal of the Brazilian Chemical Society 21:105-111 doi: 10.1590/S0103-50532010000100016

Vargas-Méndez LY, Castelli MV, Kouznetsov VV, Urbina JM, López SN, Sortino M, et al. (2003) In vitro antifungal activity of new series of homoallylamines and related compounds with inhibitory properties of the synthesis of fungal cell wall polymers. Bioorganic $\mathbb{d}$ Medicinal Chemistry 11:1531-1550 doi: 10.1016/S09680896(02)00605-3

Weitzman I, Summerbell RC (1995) The Dermatophytes. Clinical Microbiology Reviews 8:240-259

Wallace OB, Lauwers KS, Jones SA, Dodge JA (2003) Tetrahydroquinoline-based selective estrogen receptor modulators (SERMs). Bioorganic \& Medicinal Chemistry Letters 13:1907-1910 doi: 10.1016/S0960894X(03)00306-8

Woodfolk JA (2005) Allergy and Dermatophytes. Clinical Microbiology Reviews 18:30-43 doi: 10.1128/CMR.18.1.3043.2005

Zacchino SA, López SN, Pezzenati GD, Furlán RL, Santecchia CB, Muñoz L, etal. (1999) In Vitro Evaluation of Antifungal Properties of Phenylpropanoids and Related Compounds Acting Against Dermatophytes. Journal of Natural Products 62:1353-1357 doi: 10.1021/ np9805443

Zheng QZ, Cheng K, Zhang XM, Liu K, Jiao QC, Zhu HL (2010) Synthesis of some $N$-alkyl substituted urea derivatives as antibacterial and antifungal agents. European Juornal of Medicinal Chemistry 45:3207-3212 doi: 10.1016/j.ejmech.2010.03.027 
Síntesis y evaluación in vitro de las propiedades antifúngicas de algunos derivados de 4-aril-3-metil1,2,3,4-tetrahidroquinolinas

Resumen. Dos series de 4-aril-3-metil-1,2,3,4tetrahidroquinolinas fueron sintetizadas de acuerdo con una metodología sintética de dos pasos y evaluadas como potenciales agentes antifúngicos. El paso clave involucró la formación de las correspondientes $\mathrm{N}$-bencil tetrahidroquinolinas 5 vía una cicloadición imino Diels-Alder catiónica. El segundo paso consistió en obtener las tetrahidroquinolinas N-desprotegidas 6 vía una desbencilación catalítica. Los productos fueron aislados y purificados usando cromatografía en columna (CC). Las sustancias fueron identificadas usando resonancia magnética nuclear (RMN), espectrometría de masas (EM) y espectroscopia infrarroja (IR). Los compuestos fueron evaluados in vitro frente a cepas estandarizadas de hongos clínicamente relevantes, incluyendo levaduras, hialohifomicetes y dermatofitos. Estos estudios mostraron que, de las tetrahidroquinolinas ensayadas, los compuestos of y $6 \mathrm{~g}$ mostraron actividad antifúngica, específicamente frente a dermatofitos. El compuesto 6-metoxi-4-(4-hidroxi-3-metoxifenil)-3-metil-1,2,3,4tetrahidroquinolina $6 \mathrm{~g}$ exhibió la mejor actividad (MIC 32-65 $\mu \mathrm{g} / \mathrm{mL}$ ). Los resultados indican que remover el grupo bencilo e introducir un grupo hidroxilo en el sustituyente arilo de las $\mathrm{N}$-bencil tetrahidroquinolinas produce un mejoramiento de la actividad antifúngica. Predicciones in silico complementaron los resultados: la mayoría de las tetrahidroquinolinas ensayadas mostraron alta biodisponibilidad, altos "drug scores" y bajo riesgo potencial.

Palabras clave: actividad antifúngica; tetrahidroquinolinas; reacción imino Diels-Alder catiónica, regla de Lipinski, propenilbencenos
Síntese e avaliação in vitro das propriedades antifúngicas de alguns derivados de 4-Aryl-3-Methyl-1,2,3,4Tetrahydroquinolines

Resumo.Duas séries de 4-aril-3-metil-1,2,3,4-tetrahidroquinolina foram sintetizadas de acordo com um método de síntese em duas etapas e avaliadas como potenciais agentes antifúngicos. $\mathrm{O}$ passo chave envolveu a formação dos correspondentes N-bencil tetrahidroquinolinas 5 via uma cicloadição de imino Diels-Alder catiónica. O segundo passo foi obter as $\mathrm{N}$-tetrahidroquinolinas 6 através de uma desbenzilação catalítica. Os produtos foram purificados utilizando cromatografia em coluna. As substâncias foram identificadas por ressonância magnética nuclear (RMN), espectrometria de massa (EM) e espectroscopia de infravermelho (IR). Todos o compostos foram testados in vitro contra as estirpes padrão e os fungos clinicamente importantes, incluindo as leveduras, hialohifomicetes e dermatófitos. Estes estudos mostraram que entre a série de tetrahidroquinolinas (THQ) os compostos of e $6 \mathrm{~g}$ mostraram atividade antifúngica, particularmente contra dermatófitos. O composto 6-metoxi-4(4-hidroxi-3-metoxifenil)-3-metil-1,2,3,4-tetrahidroquinila $6 \mathrm{~g}$ mostrou melhor atividade (MIC 32-65 $\mu \mathrm{g} / \mathrm{mL}$ ). Os resultados indicam que a remoção do grupo benzilo e a introdução de um grupo hidroxilo no substituinte arilo do N-benziltetrahidroquinolina, resultou num aumento significativo da atividade antifúngica. Os resultados foram suplementados por previsões in silico, que mostraram alta biodisponibilidade e pouco risco potencial da maioria dos tetrahidroquinolinas avaliados.

Palavras-chave: atividade antifúngica; tetrahidroquinolinas; reação imino Diels-Alder catiónica, regra de Lipinski, propenilbencenos 